\title{
EFEKT CHARAKTERISTIK ÚZEMÍ NA PARKOVACÍ MINIMA
}

\author{
EFFECT OF LOCALITY CHARACTERISTICS \\ ON PARKING REQUIREMENTS
}

\author{
Hana Kobzová*,1, Lucie Kejvalová \\ "kobzova.h@fce.vutbr.cz \\ ${ }^{1}$ Vysoké učení technické v Brně, Fakulta stavební, Ústav pozemních komunikací, Veveří 331/95, 60200 Brno, Česká republika
}

\begin{abstract}
Abstrakt
Na základě rozsáhlé rešerše předpisů devíti sledovaných středoevropských měst popisuje článek rozdíly ve stanovování minimálního počtu parkovacích stání v závislosti na lokalitě a demonstruje je na konkrétním výpočtu pro modelovou blokovou zástavbu umístěnou ve třech různých situacích. Výzkum ukazuje, že města přistupují k charakteristikám území poměrně rozdílně, některá z nich například charakteristiky území neřeší vůbec, jiná oproti tomu díky nim umožňují redukci až na 10 \%. Práce popisuje všechny tyto charakteristiky a způsoby jejich zahrnutí rozděluje na tři základní přístupy. Tím se snaží poskytnout vhled do problematiky ve sledovaných městech pro aktualizaci ČSN 736110 a tvorbu místních stavebních předpisů.
\end{abstract}

\section{Klíčová slova}

Požadavky na výstavbu parkovacích stání, parkovací minima, parkovací politiky, stavební předpisy

\begin{abstract}
Based on extensive research of regulations in nine Central European cities the article describes the differences in setting the minimum number of parking spaces based on locality. For that, it uses a calculation of a model housing block located in three different situations. Research shows that cities approach the locality characteristics quite differently. Some do not take locality characteristics into account at all. Others allow reduction up to $10 \%$. Paper describes all the characteristics and divides the means of their inclusion into three general branches. Thus it attempts to provide insight into the problematics in selected cities to foster the Czech National Standard 736110 update and local construction regulations creation.
\end{abstract}

Key words

Parking requirments, parking minimums, parking policies, building code

\section{1 ÚVOD}

Článek navazuje na příspěvek autorek věnovaný trendům v nastavení parkovacích minim ve středoevropských městech, který mimo jiné upozornil i na různé přistupy k redukci a navyšování požadovaného počtu stání v závislosti na lokalitě řešeného objektu. Tento článek shrnuje podrobnější analýzu těchto rozdílů a rozdíly demonstruje na třech modelových situacích lišících se polohou rozvojové lokality a napojením MHD. Cílem př́spěvku je popsat jaký má na výsledné minimum dopad dostupnost MHD, charakter území, vzdálenost od centra a jaké další vstupy spojené s lokalitou mají na parkovací minima ve sledovaných městech vliv. Tím si klade za cíl přinést relevantní podklady pro aktualizaci kapitoly 14.1. Odstavné a parkovací plochy normy ČSN 736110 Projektování místních komunikací, př́ípadně pro přípravu místních stavebních předpisů, které si dle nového stavebního zákona mohou nově mimo Prahy vytvořit i Brno a Ostrava.

\section{LITERÁRNÍ PřEHLED/POPIS SOUČASNÉHO STAVU}

Většina pozornosti věnovaná požadavkům na parkovací minima pochází z USA a Asie, kde v minulosti a v některých místech i dnes byly požadavky na výstavbu stání extrémně přemrštěné. Mezi nejvýznamnější osobnosti věnující se této problematice patří např́íklad profesor urbanismu Donald Shoup z Kalifornské univerzity 
v LA. V jeho nejznámější publikaci The High Cost of Free Parking [1] se věnuje takzvané parkovací ekonomii a zákonu nabídky a poptávky aplikovaném na parkování.

Např́č kontinenty se však dopravní chování a politiky celkem výrazně liší [1], a proto je často nevhodné srovnávat poměry a trendy např. právě v USA s poměry České republiky. I proto se práce zaměřuje na středoevropské státy a města.

V kontextu Evropy není téma parkovacích minim probádáno v takové míře, nicméně v posledních letech vzniklo několik publikací, které se tomuto tématu věnují. Ku príkladu v roce 2011 byla Michaelem Kodranskym a Gabrielle Hermanne vydána publikace Europe's Parking U-Turn: From Accommodation to Regulations [2], která popisuje komplexně parkovací politiky desíti západoevropských měst (Amsterdam, Kodaň, Mnichov atd.). V této publikaci je pozornost částečně věnována právě i parkovacím minimům, nicméně metodiky jsou zde jen stručně popsány, a to jen pro některá města.

Kontextu středoevropských měst navazují autorky zejména na svojí předchozí práci. Nejzásadněji na př́spěvek, Trends in Parking Requirements Policies in Central European Cities [3], který se zaměřil na srovnání trendů v devíti středoevropských městech. Na modelové zástavbě, která je použita i pro tuto analýzu, byly demonstrovány rozdíly v potřebných počtech stání pro blokovou zástavbu v centru města. Protože rozdílům v požadavcích daných lokalitou byla věnovaná jen okrajová pozornost, je toto téma šíře rozebráno v tomto článku.

\section{METODIKA}

V prvním kroku byly podrobně prostudovány předpisy devíti vybraných měst a prrípadné nejasnosti byly konzultovány s místními odborníky. Dále byla pro demonstraci rozdílů v nastavování minim využita modelová bloková zástavba sestavená dle existující zástavby v centrální části města Brna, konkrétně čtvrtě Veveří. Pro ni byly stanoveny minimální požadavky na výstavbu stání ve třech různých situacích, které odpovídají tř̌em rozvojovým lokalitám dle Návrhu Územního plánu města Brna [4]. První situace odpovídá umístění zástavby do rozvojové lokality Nová čtvrt' Trnitá v blízkosti historického centra. Druhá a třetí situace odpovídá dvěma rozvojovým lokalitám v okrajové městské části Bosonohy, které leží sice poměrně blízko u sebe, ale liší se charakterem a dostupností MHD.

\section{Sledované předpisy}

Článek popisuje výstupy výzkumu FAST-J-21-7523 Trendy v politice parkovacích minim v evropských zemích a jejich vliv na udržitelný rozvoj měst, který mapuje předpisy středoevropských měst a srovnává je z různých hledisek. Jako střední Evropa jsou pro účely tohoto výzkumu chápány státy: Německo, Polsko, Slovensko, Rakousko a Česká republika a jako vybraná města byla zvolena města popsaná tabulkouTab. 1 Sledované předpisy.:

Tab. 1 Sledované předpisy.

\begin{tabular}{cc}
\hline & Předpis \\
\hline Berlin & BauO Bln [5] \\
Bratislava & STN 73 6110 [6] \\
Brno & ČS 73 6110 [7] \\
Graz & HBauO [9] \\
Hamburg & Leitfaden Mobilität für Bauvorhaben [8] \\
Krakov & Program Obsługi Parkingowej dla Miasta Krakowa [10] \\
Norimberk & Stellplatz 630.746 [11] \\
Praha & PSP [12] \\
Vídeň & WGarG 2008 [13] \\
& Bauordnung für Wien [14]
\end{tabular}

\section{Modelová zástavba}

Jako základ pro modelovou blokovou zástavbu byl vybrán skutečný blok v brněnské čtvrti Veveří vymezený ulicemi Antonínská, Botanická, Smetanova a Cihlářská, který odpovídá smíšené obytné zástavbě s kompaktní zástavbou, pro kterou jsou vymezeny plochy ve sledovaných rozvojových lokalitách. Zastoupení jednotlivých funkcí, stejně jako příslušných účelových jednotek v zástavbě vyjadřuje Tab. 2 Modelová zástavba. 
Tab. 2 Modelová zástavba.

\begin{tabular}{|c|c|c|c|c|c|}
\hline & \multicolumn{2}{|c|}{ HPP } & \multirow[t]{2}{*}{$\%$ z HPP } & \multicolumn{2}{|r|}{ účelové jednotky } \\
\hline \multirow{4}{*}{ Bydlení } & & & & 11692 & m2 bytové plochy \\
\hline & 16239 & $\mathrm{~m} 2$ & $68 \%$ & 146 & bytů \\
\hline & & & & 292 & obyvatele \\
\hline & & & & 631 & $\mathrm{~m} 2$ prodejní plochy \\
\hline \multirow[t]{2}{*}{ Prodejny } & 971 & $\mathrm{~m} 2$ & $4 \%$ & 7 & prodejen \\
\hline & & & & 10 & zaměstnanců \\
\hline \multirow{3}{*}{ Kanceláře } & 462 & $\mathrm{~m} 2$ & 20 & 300 & m2 kancelářské plochy \\
\hline & 402 & $\mathrm{~m} 2$ & $2 \%$ & 19 & zaměstnanců \\
\hline & & & & 4567 & $\begin{array}{c}\text { m2 tříd a prostorů pro } \\
\text { žáky }\end{array}$ \\
\hline \multirow[t]{3}{*}{ Základní škola } & 6343 & $\mathrm{~m} 2$ & $26 \%$ & 500 & žáků \\
\hline & & & & 35 & zaměstnanců \\
\hline & & & & 28 & tř́idy \\
\hline
\end{tabular}

Pro odhad rozdělení funkcí využití byl použit „Průzkum budov, KAM 2019“ [15] a „Průzkum maloobchodu, KAM 2018“ [16]. Pravá část tabulky pak vyjadřuje zastoupení jednotlivých účelových jednotek pro stanovení potřebných parkovacích stání, jako např́íklad užitné podlažní plochy, počty zaměstnancủ, žáků atd. Protože se jedná o poměrně podrobné informace, které nejsou z běžných zdrojů dostupné, byly tyto hodnoty odhadnuty pomocí koeficientů užívaných v územních studiích KAM (např. Územní studie Jižní čtvrt' [17]). Užitná plocha pro bydlení byla stanovena jako $72 \%$ hrubé podlažní plochy (HPP). Počet bytů byl stanoven prostým podílem $80 \mathrm{~m} 2 /$ byt, pro každý takový byt byly odhadnuti 2 obyvatelé. Prodejní plocha byla stanovena jako $65 \%$ HPP, počet zaměstnanců pro všechny prodejny dohromady byl odhadnut celkem na 10 . Všude tam, kde se vyskytovala komerce, ale zároveň se v místě nenacházela prodejna dle [16], byla funkční plocha určena jako plocha kancelárí. Kancelářská plocha pak byla stanovena podobně jako u obchodu $65 \%$ HPP a počet zaměstnanců byl odhadnut dle ČSN 735303 Administrativní budovy a prostory [18], která uvažuje jako doporučenou hodnotu 16 m2 na zaměstnance. Užitná plocha školy byla opět odhadnuta jako $72 \%$ HPP. Kapacita stejně jako počet zaměstnanců a počet tříd byla odečtena z výroční zprávy ZŠ a MŠ Antonínská [19].

\section{Sledované lokality}

Pro srovnání byly vybrány tři rozvojové lokality z Návrhu územního plánu města Brna, a to Nová čtvrt' Trnitá v těsné blízkosti historického centra, s velmi dobrou dopravní obsluhou (v blízkosti se nachází dnešní tramvajový uzel Hlavní nádraží a budoucí tramvajové uzly Malá Amerika a Nové nádraží). Další dvě lokality se nachází v okrajové městské části Bosonohy. Dle územní studie Bosonohy [20] je uvažována lokalita Křivánky jako lokalita v lokálním centru, s napojením na páteřní tramvajovou rychlodráhu (prodloužené dnešní linky 6 a 8 ) a lokalita Kostky, kde je tramvaj dle studie v rezervě a v popisované analýze bylo uvažováno bez jejího vybudování, a tedy s horší dopravní obslužností. Při aplikaci zahraničních předpisů pak byla v daných městech vybírána pravidla pro stanovení minimálního počtu stání pro obdobné lokality tak, aby co nejvíce odpovídaly charakteru těch brněnských. Poloha jednotlivých lokalit je zobrazena ná následujícím obrázku Obr. 1.

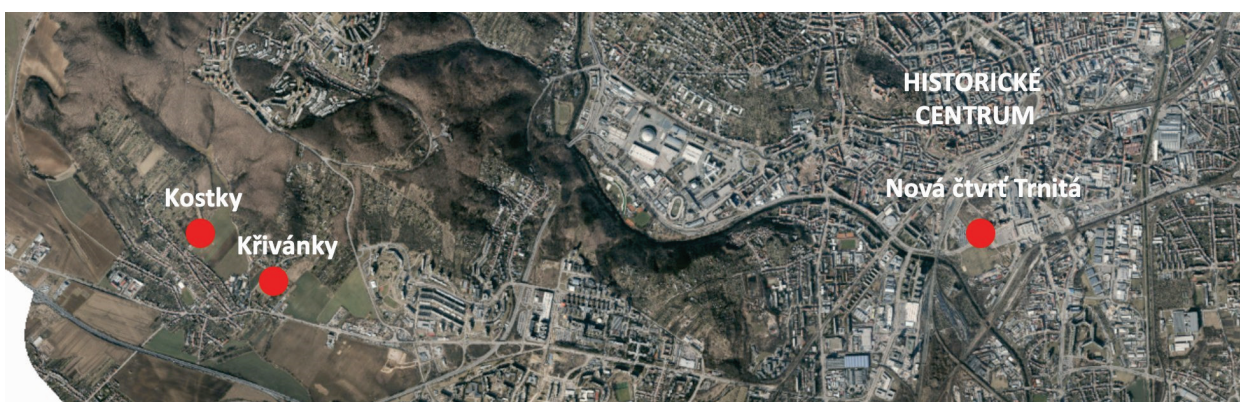

Obr. 1 Sledované lokality. 
V každé z těchto lokalit se nachází zastavitelné plochy smíšené obytné s kompaktní zástavbou. Rozdílné jsou výškové regulace pro jednotlivé lokality, nicméně protože byla pro všechny lokality uvažovaná stejně vysoká modelová zástavba, byla výšková regulace zanedbána.

\section{VÝSLEDKY}

V následující tabulce Tab. 3 Minimální počty stání pro sledované situace můžeme vidět stanovené minimální počty parkovacích stání pro sledovanou blokovou zástavbu ve třech výše popsaných situacích.

Tab. 3 Minimální počty stání pro sledované situace.

\begin{tabular}{|c|c|c|c|c|c|}
\hline & Bydlení & Prodejny & Kanceláře & $\mathbf{Z S}$ & Celkem \\
\hline \multicolumn{6}{|c|}{ Nová čtvrt' Trnitá } \\
\hline Berlín & 0 & 0 & 1 & 2 & 3 \\
\hline Bratislava & 246 & 8 & 5 & 2 & 246 \\
\hline Brno & 188 & 4 & 3 & 31 & 226 \\
\hline Graz & 18 & 2 & 1 & 1 & 21 \\
\hline Hamburk & 0 & 8 & 6 & 56 & 70 \\
\hline \multirow{2}{*}{ Krakov $\begin{array}{l}\min \\
\max \end{array}$} & 146 & 6 & 2 & 12 & 166 \\
\hline & 292 & 13 & 3 & 29 & 337 \\
\hline Norimberk & 117 & 6 & 7 & 30 & 160 \\
\hline Praha & 122 & 2 & 6 & 8 & 138 \\
\hline \multirow[t]{2}{*}{ Vídeň } & 12 & 2 & 1 & 15 & 14 \\
\hline & \multicolumn{5}{|c|}{ Křivánky } \\
\hline Berlín & 0 & 0 & 1 & 2 & 3 \\
\hline Bratislava & 251 & 17 & 10 & 3 & 281 \\
\hline Brno & 194 & 10 & 7 & 75 & 286 \\
\hline Graz & 90 & 14 & 4 & 7 & 114 \\
\hline Hamburk & 0 & 8 & 6 & 56 & 70 \\
\hline \multirow{2}{*}{ Krakov $\quad \begin{array}{l}\min \\
\max \end{array}$} & 350 & 19 & 9 & 57 & 435 \\
\hline & - & - & - & - & - \\
\hline Norimberk & 146 & 8 & 9 & 37 & 200 \\
\hline Praha & 184 & 9 & 9 & 19 & 221 \\
\hline \multirow[t]{2}{*}{ Vídeň } & 59 & 1 & 1 & 8 & 69 \\
\hline & & Kostky & & & \\
\hline Berlín & 0 & 0 & 1 & 2 & 3 \\
\hline Bratislava & 258 & 28 & 17 & 6 & 309 \\
\hline Brno & 202 & 16 & 11 & 125 & 354 \\
\hline Graz & 180 & 26 & 8 & 13 & 227 \\
\hline Hamburk & 0 & 8 & 6 & 56 & 70 \\
\hline \multirow{2}{*}{$\begin{array}{ll}\text { Krakov } & \min \\
\max \end{array}$} & 350 & 19 & 9 & 57 & 435 \\
\hline & - & - & - & - & - \\
\hline Norimberk & 146 & 8 & 9 & 37 & 200 \\
\hline Praha & 189 & 13 & 9 & 23 & 234 \\
\hline Vídeň & 117 & 2 & 1 & 15 & 135 \\
\hline
\end{tabular}

\section{DISKUZE}

Na stanovených minimálních počtech stání na modelové blokové zástavbě ve třech různých situacích vidíme, že zatímco podle předpisů některých měst se minimální počty stání výrazně liší, u některých není výsledný počet stání na lokalitě závislý vůbec. Mezi města, ve kterých lokalita na počet stání nemá žádný vliv patří Berlín, zde jsou však povinně stanovována pouze stání pro zdravotně tělesně postižené (ZTP), zbytek je na vlastním uvážení stavebníků [5]. Dalším městem, kde lokalita nerozhoduje je Hamburk i zde je částečně závislý výsledný počet jen na stavebníkovi - v Hamburku totiž není nutné dokládat stání pro rezidenty [9]. 
Bratislava zohledňuje při stanovení parkovacích minim lokalitu regulačním koeficientem městské polohy [6]. Tento koeficient rozlišuje celkem šest typů území, pro které stanovuje různou velikost koeficientu od historického jádra s koeficientem 0,05 po ostatní lokality s koeficientem 1,00 [6]. Na Slovensku, pro které předpis sledovaný v Bratislavě platí, se tento koeficient ovšem nevztahuje na stání pro rezidenty [6]. Pro námi sledované lokality byly zvoleny koeficienty 0,3 pro "centrální městskou zónu" pro Trnitou, 0,6 "lokální centrum MČ" pro Křivánky a 1,0 "ostatní území pro Kostky". Mimo to se ve slovenském předpisu pracuje ještě se "součinitelem vlivu dělby přepravní práce" [6]. Tu lze v řešených lokalitách očekávat různá, vzhledem $\mathrm{k}$ dostupnosti MHD, ostatní infrastruktury (tzv. "walkscore") nebo cyklistické infrastruktury. Pro uplatnění tohoto koeficientu ovšem nebyly dohledány relevantní data, o která by se jeho volba mohla opřít, a proto bylo ve všech př́ípadech uvažováno s jeho základní hodnotou 1,0 pro poměr 40:60 IAD:ostatní doprava. Tento koeficient může nabývat hodnot od 0,8 do 1,4 [6].

V Brně na sledovaných situacích můžeme pozorovat, že podobně jako na Slovensku se počet stání pro bydlení liší jen minimálně, koeficient zohledňujících lokalitu se totiž taktéž nevztahuje na stání pro rezidenty a rozdíl tak tvoři stání pro návštěvy, které jsou nutné u staveb pro bydlení vybudovat [7]. Zmíněný koeficient zohledňující lokalitu se nazývá "koeficient redukce počtu stání", lze jej určit podle tabulky dle charakteru území nebo výpočtem koeficientu dostupnosti MHD [7]. Koeficient nabývá hodnot 0,25 - 1,00 [7].

Graz má celkem tři skupiny počtů účelových jednotek na stání, které jsou závislé na typu lokality - úzké centrum, širší centrum a ostatní území [8]. V popisované analýze byly využity koeficienty pro širší centrum pro Novou čtvrt' Trnitou a koeficienty pro ostatní území pro Křivánky a Kostky. Třetí, v analýze nevyužitá, skupina koeficientů se vztahuje na historické centrum. Pomocí těchto koeficientů stanovený minimální počet stání lze následně ještě dále zredukovat dle dostupnosti MHD až na $10 \%$ [8]. U tohoto koeficientu bylo postupováno obdobně jako ve Vídni, a tedy redukce na $10 \%$ byla využita u Trnité, pro Křivánky vzhledem k napojení na tramvajovou rychlodráhu byla uvažována redukce na $50 \%$ a pro Kostky pak redukce nebyla použita.

Krakov má dvě skupiny základních počtů stání na účelové jednotky a jejich použití je ohraničeno "hranicí funkčního města", která odpovídá přibližně hranici širšího centra [10]. Nižší koeficienty byly užity jen pro Novou čtvrt' Trnitá. Pro tuto část města jsou pak navíc vymezeny i maximální počty stání, které je u záměru možné vybudovat. Pro zbytek města jsou pak použity vyšší koeficienty, ty byly uvažovány pro rozvojové lokality Křivánky a Kostky. Požadavky stanovené pomocí těchto koeficientů jsou výrazně vyšší než minima i maxima v centrální části a nelze je dále redukovat ani při kvalitní dostupnosti MHD [10].

V Norimberku je v oblasti uvnitř okruhu tvořeného silnicí 4R možné redukovat minimální počet stání na 80 \% [11]. Toto snížení bylo aplikováno pro oblast Nová čtvrt' Trnitá a pro zbylé dvě rozvojové lokality v okrajové části nebylo možné žádnou redukci použít.

V Praze vstupuje lokalita záměru do výpočtu poměrně významně [12]. Celé území Prahy je rozdělené do devíti lokalit [12]. Pro každou z těchto lokalit je stanovené \% ze základního počtu stání, které je v této lokalitě nutné zřídit [12]. V zónách blíže k centru je počet stání omezen i shora maximálním \% které je možné postavit, tyto maxima se ovšem nevztahují na stání pro rezidenty [12]. Pro lokalitu Nová čtvrt’ Trnitá byly použity procenta pro zónu 01 která odpovídá lokalitě přilehlé k historickému centru, to znamená, že základní počet stání pro rezidenty bylo uvažováno $60 \%$ a u zbytku jen $10 \%$, pro stání, která nejsou určena rezidentům pak PSP předepisují I maximum, které v této zóně odpovídá $35 \% .60 \%$ pro všechny stání bylo uvažováno pro Křivánky a odpovídá zónám v okolí zastávek metra v Praze (zóny 05). S lokalitou Kostky bylo uvažováno jako se zónou 07, která odpovídá okrajovým zastavitelným územím a požaduje se v ní 90 \% základních stání.

Vídeň používá jednotné koeficienty pro celé město s tím, že je možné běžně redukovat tento počet na $50 \%$ v případě dobré dostupnosti MHD, která se prokazuje dostupností zastávky do $300 \mathrm{~m}$, tuto podmínku dle ÚS Bosonohy (KAM, 2021) splňují i plochy v rozvojové lokalitě Křivánky [13], [14]. V případě velmi dobré dostupnosti MHD je možné redukovat počet stání až na $10 \%$, tato redukce byla využita pro Novou čtvrt' Trnitá, protože se v měřítku města jedná o výjimečně dobře obslouženou čtvrt' z hlediska hromadné dopravy [13], [14]. V případě velmi špatné obsluhy MHD, zastávka dál než $500 \mathrm{~m}$ od záměru lze požadovat $110 \%$ základního počtu parkovacích stání, v oblasti Kostky se plochy pro smíšenou obytnou blokovou zástavbu nachází do 500 m od stávajících zastávek MHD a s postupem výstavby se dá předpokládat spíše rozšíření sítě zastávek MHD, pro tuto lokalitu bylo tedy stanoveno $100 \%$ stání [13], [14].

\section{ZÁVĚR}

Článek shrnuje trendy v nastavování parkovacích minim ve vybraných středoevropských městech z hlediska vlivů charakteristik lokality, ve které se sledovaný záměr nachází, shrnuje ty nejvýznamnější z nich a demonstruje je na výpočtu požadovaných stání na reálné kompaktní smíšené obytné zástavbě ve třech různých situacích. Na těchto situacích se ukazuje, že města, která mají obecně nastavená minima velmi nízko, nepožadují více stání ani v okrajových lokalitách. Obecně se objevují mezi sledovanými předpisy prakticky tři př́stupy - žádná redukce v Berlíně a Hamburku, kdy Berlín nevyžaduje dokládat žádná stání kromě těch pro ZTP a Hamburk nevyžaduje 
dokládat stání pro rezidenty. Redukce základního počtu stání dalšími součiniteli zohledňující charakter území (Brno, Bratislava), dostupnost MHD (Brno, Graz, Vídeň), modal split (Bratislava) a předem definované městské zóny (Norimbek a Praha) a poslední př́stup, který je založený na různých základních koeficientech pro účelové jednotky pro stanovení základního počtu stání (Graz, Krakov).

\section{Poděkování}

Výzkum vznikl za podpory juniorského specifického výzkumu FAST-J-21-7523 Trendy v politice parkovacích minim v evropských zemích a jejich vliv na udržitelný rozvoj měst. Mimoto je nutné poděkování věnovat I Kanceláři architekta města Brna, za poskytnutí dat a zahraničním odborníkům se kterými byly konzultovány předpisy sledovaných měst.

\section{Použité zdroje}

[1] Donald Shoup, The High Cost of Free Parking, A Olanners Press Book, 2005.

[2] Michael Kodransky, Gabrielle Hermann, Europe's Parking U-Turn: From Accommodation to Regulation, ITDP, 2011.

[3] Hana Kobzová, Trends in Parking Requirements Policies in Central European Cities, dosud nevydáno.

[4] KAM Brno, Návrh Územního plánu města Brna, 2020.

[5] Berliner Vorschriften- und Rechtsprechungsdatenbank, „Bauordnung für Berlin,“ 2017. [Online]. Available: https://gesetze.berlin.de/bsbe/document/jlr-BauOBE2005V7P49.

[6] Slovenský ústav technickej normalizácie, „STN 736110 Projektovanie miestnych komunikácií,“2004. [Online].

[7] Český normalizační institut, „ČSN 736110 - Projektování místních komunikací,“ 2006. [Online]. Available: https://www.mmr.cz/cs/ministerstvo/stavebni-pravo/pravo-a-legislativa/prehled-platnychpravnich-predpisu/dalsi-predpisy/norma-csn-73-6110-projektovani-mistnich-komunika.

[8] Abteilung für Verkehrsplanung, „LEITFADEN MOBILITÄT FÜR BAUVORHABEN,“ 2016. [Online]. Available: https://www.graz.at/cms/dokumente/10299565 7759220/ea3f774e/Leitfaden\%20Mobilit\%C3\%A4t\% $20 \mathrm{f} \% \mathrm{C} 3 \% \mathrm{BCr} \% 20 \mathrm{Bauvorhaben.pdf.}$

[9] „§ $\$ 8 \mathrm{HBauO}$ Hamburgische Bauordnung (HBauO),“ [Online]. Available: http://www.lexsoft.de/normensammlung/1540888,55.

[10] „Program Obsługi Parkingowej dla Miasta Krakowa,“ [Online]. Available: https://www.bip.krakow.pl/?dok_id=52386.

[11] „Satzung über die Herstellung und Bereithaltung von Kraftfahrzeugstellplätzen und Fahrradabstellplätzen, “ 2016. [Online]. Available: https://www.nuernberg.de/imperia/md/stadtrecht/dokumente/6/630/630_746.pdf.

[12] Institut plánování a rozvoje hlavního města Prahy, „Pražské stavební předpisy s aktualizovaným odůvodněním,“ 2018. [Online]. Available: https://www.iprpraha.cz/uploads/assets/dokumenty/psp/psp_2018_web.pdf.

[13] „Landesrecht konsolidiert Wien: Wiener Garagengesetz 2008 § 50,“ 2018. [Online]. Available: https://www.ris.bka.gv.at/NormDokument.wxe?Abfrage $=$ LrW\&Gesetzesnummer=20000052\&Fassun $\mathrm{gVom}=2019-07-08 \&$ Artikel $=\&$ Paragraf $=50 \&$ Anlage $=\&$ Uebergangsrecht $=$.

[14] „Bauordnung für Wien,“ [Online]. Available: https://www.ris.bka.gv.at/NormDokument.wxe?Abfrage $=$ LrW\&Gesetzesnummer=20000006\&Artikel $=\&$ Paragraf $=119 \&$ Anlage $=\&$ Uebergangsrecht $=$.

[15] KAM Brno, „Budovy v Brně,“ 2020. [Online]. Available: http://webmaps.kambrno.cz/budovy/.

[16] KAM Brno, „Maloobchodní sít’ Brna,“ 2017. [Online]. Available: http://webmaps.kambrno.cz/maloobchod/.

[17] KAM Brno, „Územní studie Jižní čtvrt',“ [Online]. Available: https://upmb.brno.cz/uzemne-planovacipodklady/uzemni-studie/platne-us/uzemni-studie-jizni-ctvrt/.

[18] Český normalizační institut,, „ČSN 735305 Administrativní budovy a prostory,“ [Online].

[19] Základní škola a mateřská škola Brno, Antonínská 3, příspěvková organizace, „Výroční zpráva ředitele školy," 2019/2020. [Online]. Available: https://www.zsantoninska.cz/wpcontent/uploads/2015/05/VZ19-20_Z\%C5\%A0aM\%C5\%A0-Anton\%C3\%ADnsk\%C3\%A1final.pdf.

[20] KĀ̄M Brno, ÚS lokalita Bosonohy, dosud nevydáno, 2021. 